\title{
Wear of PVD coated tools for joining by clinching method
}

\section{Opotrebovanie nástrojov pre spájanie materiálov metódou Clinching povlakovaných PVD vrstvami}

\author{
Kubik R., Kaščák L., Spišák E. \\ Institute of Technology and Management, Faculty of Mechanical Engineering, Technical University of Košice \\ E-mail: rene.kubik@tuke.sk
}

Clinching is a joining method in which sheet metal parts are deformed locally by creating a mechanical interlock without the use of any additional elements such as screws or rivets. Steel sheets are plastically deformed and the shape of the tools remains theoretically unchanged during the clinching process. The clinching tool with a rigid die of $\varnothing 5 \mathrm{~mm}$ with a specially formed gap and a punch of $\varnothing 3.6 \mathrm{~mm}$ were used for mechanical joining of hot-dip galvanized dual-phase steel sheets HCT600X of $0.8 \mathrm{~mm}$ thickness. The punch and die were deposited by PVD coating of CrN and TiCN type with LARC technology. The state of the coating was evaluated and documented by scanning electron microscopy - SEM. The wear of the coating was evaluated after each 50 manufactured joints starting with the initial state of tool.

\section{INTRODUCTION}

PVD protective layers are applied to clinching tools to provide sufficient protection against wear. Depending on the requirements of the application, single or multilayer PVD coatings can be utilized for this purpose [1]. Hard physical vapour deposition coatings have been found to improve the fatigue life of coating-substrate systems especially steel substrates at high cycle fatigue regions. Multi-element PVD coatings with various mechanical strengths or single-element coatings are used to improve the mechanical and tribological properties and the chemical stability of coated components [2,3]. Surface coating on tools can provide high wear resistance, increase surface hardness at high temperatures and create a chemical barrier against diffusion or reaction between the tool and the workpiece. The basic properties of PVD coatings include adhesion, hardness, thickness and roughness [4].

One of the areas where PVD coatings are used to increase tool wear resistance is mechanical joining of materials. One of the most common mechanical joining processes in the manufacturing of sheet metal products is clinching, especially where it is required that no
Clinching je metóda spájania materiálov vo forme plechov kde dochádza $k$ ich lokálnej deformácii vytvorením mechanického zakliesnenia a to bez použitia akýchkol'vek prídavných elementov, napriklad vo forme skrutiek alebo nitov. Ocel'ové plechy sú plasticky deformované a tvar nástroja zostáva teoreticky nezmenený v priebehu spájania metódou Clinching. Pre mechanické spájanie pozinkovaných dvojfázových oceli (HCT600X) vo forme tenkých plechov o hrúbke 0,8 $\mathrm{mm}$ bol použitý nástroj, ktorý pozostáva z pevnej lisovnice so špeciálne tvarovanou dutinou o priemere $\varnothing 5 \mathrm{~mm}$ a lisovnika o priemere ø3,6 mm. Na povrch lisovníka a lisovnice boli metódou LARC nanesené PVD povlaky typu CrN a TiCN. Stav povlakov bol hodnotený a dokumentovaný riadkovacím elektrónovým mikroskopom (REM). Opotrebovanie povlakov bolo hodnotené po 50 vyrobených spojoch, pričom experimentálna čast' začina východiskových stavom nástrojov.

additional joining elements are used. The typical field utilizing this joining method is automotive industry, whose current trends require lower energy consumption. The most effective way of producing more energyefficient vehicles is the reduction of the car body weight. Number of various lightweight materials such as hotdip zinc coated metals, aluminium alloys and even magnesium alloys are used. These materials cannot be joined effectively by traditional techniques, e.g. resistance spot welding. Therefore, alternative joining methods are being developed and used. Mechanical clinching is an increasingly used alternative joining method in the automotive industry. This method is utilized for joining similar or dissimilar materials, precoated or galvanized sheets up to a total thickness of 3 $\mathrm{mm}$ [5-7]. The cold forming clinching process joins two or more sheets placed between the appropriate punch and die. A cup is formed on the underside and provides an interlock between the metal sheets [8]. Clinching is a joining process that does not affect the joined materials, since it does not induce any thermal stress to the workpieces. The process causes no heat, no splashes, no flashes or harmful light. The mechanical stability of the clinched joints is influenced by several factors such as 
correct selection of process parameters or geometry of joined materials. The main geometry of clinching tools includes: punch diameter, die diameter, depth of the die, radius of punch and die, angle of inclination of the punch and the die. These dimensions are important for the joint formation and the resulting strength of joint $[9,10]$.

The research focused on the evaluation of the wear of punch and die of the clinching tool with PVD coatings TiCN and $\mathrm{CrN}$ when joining hot-dip galvanized dualphase steel sheets HCT600X.

\section{EXPERIMENTAL WORK}

\section{Joined material}

Hot-dip galvanized, dual-phase steel sheets with thickness of $0.8 \mathrm{~mm}$ were joined by round clinching joining method. HCT600x steel grade was chosen for the experiment, whereby dual-phase steels belong into category of steels with advanced high strength also known as AHSS steels. Tab. 1 shows basic mechanical properties of the joined material and its chemical composition is shown in Tab. 2.

Sheets subjected to joining were sheared to normalized samples and contact areas of sheets were cleaned. Manufactured sample dimensions were $90 \times 40 \mathrm{~mm}$ and $30 \mathrm{~mm}$ overlapping according to STN 051122 standard.

\section{Clinching tools}

Round clinching joining process with rigid die was utilized to join two steel sheets. Final joint was manufactured with round shape and axisymmetric nature. Two types of tools were used considering the coating deposited on both tools punch and die. Further details in relation tool dimensions and deposited coatings are shown in Fig. 1.

Both clinching punch and die were manufactured from cold-working tool steel designated as X100CrMoV8-1-1 according to DIN standard, or 1.2990 according to W. Nr. These materials exhibit high hardness, good toughness and high wear resistance, hence are

Tab. 1. Fundamental mechanical properties of HCT600X steel I Základné mechanické vlastnosti oceli HCT600X

\begin{tabular}{|c|c|c|c|}
\hline $\mathbf{R}_{\mathbf{m}}[\mathbf{M P a}]$ & $\mathbf{R}_{\mathbf{p} 0.2}[\mathbf{M P a}]$ & $\mathbf{A}_{\mathbf{8 0}}[\mathbf{\%}]$ & $\mathbf{n}$ \\
\hline 600 & 330 & 20 & 0.14 \\
\hline
\end{tabular}

appropriate for punching or cold forming tools. LARC deposition process was utilized to coat the surfaces of tools. Several tests were performed to quantify coating properties such as thickness, indentation hardness, modulus of elasticity, surface roughness etc. Measured values of coating parameters are shown in Tab. 3 .

Tab. 3. Measured properties of $\mathrm{TiCN}$ and $\mathrm{CrN}$ coatings / $\mathrm{Na}$ merané vlastnosti povlakov $\mathrm{TiCN}$ a $\mathrm{CrN}$

\begin{tabular}{|c|c|c|c|c|c|}
\hline Coating & $\begin{array}{c}\mathbf{t}_{\mathbf{f}} \\
{[\boldsymbol{\mu \mathbf { m } ]}]}\end{array}$ & $\begin{array}{c}\mathbf{E} \\
{[\mathbf{G P a}]}\end{array}$ & $\begin{array}{c}\mathbf{H}_{\text {IT }} \\
{[\mathbf{G P a}]}\end{array}$ & $\begin{array}{c}\mathbf{R a} \\
{[\boldsymbol{\mu \mathbf { m } ]}]}\end{array}$ & $\begin{array}{c}\boldsymbol{\mu}-\mathrm{mean} \\
{[-]}\end{array}$ \\
\hline $\mathrm{TiCN}$ & 3.19 & 480 & 51 & 0.24 & 0.676 \\
\hline $\mathrm{CrN}$ & 1.90 & 327 & 29 & 0.21 & 0.713 \\
\hline
\end{tabular}

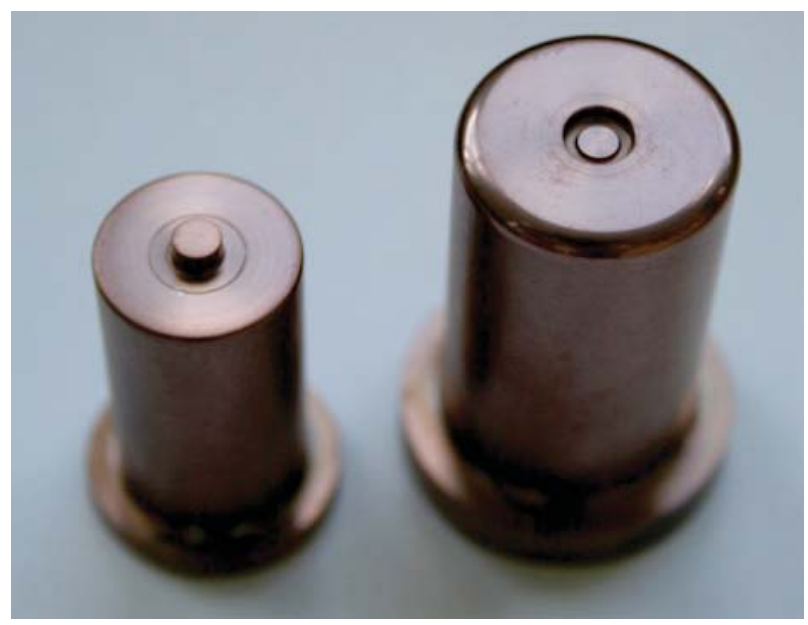

a)

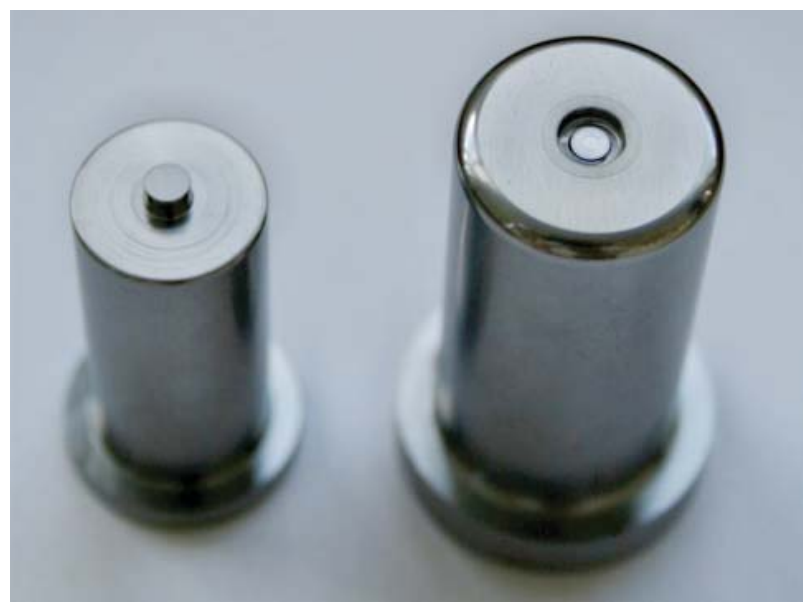

b)

Fig. 1. Clinching punch (a) and die (b) Obr. 1. Lisovník (a) a lisovnica (b)

Tab. 2. Chemical composition in \% of wt. of HCT600X steel / Chemické zloženie (percentuálny podiel) oceli HCT600X

\begin{tabular}{|c|c|c|c|c|c|c|c|c|c|c|c|c|c|c|}
\hline $\mathbf{C}$ & $\mathbf{M n}$ & $\mathbf{S i}$ & $\mathbf{P}$ & $\mathbf{A l}$ & $\mathbf{C u}$ & $\mathbf{C r}$ & $\mathbf{W}$ & $\mathbf{C o}$ & $\mathbf{V}$ & $\mathbf{N b}$ & $\mathbf{M o}$ & $\mathbf{S}$ & $\mathbf{T i}$ & $\mathbf{N i}$ \\
\hline 0.086 & 1.857 & 0.022 & 0.018 & 0.071 & 0.012 & 0.203 & $<0.002$ & 0.0015 & 0.011 & 0.016 & 0.178 & $<0.002$ & $<0.002$ & $<0.002$ \\
\hline
\end{tabular}


Initial state and wear during joining periods of both clinching punch and die was documented by means of scanning electron microscopy (Vega Tescan 3) and confocal microscopy (Sensofar PLu neox). Because of minor wear of coating deposited on the clinching die, the attention was turned to the clinching punch. Three areas of interest were defined based on the assumption that the contact of tool and the joined material should cause wear of coating. Moreover, unified direction for scanning was defined for all tools. Areas of interest and unified direction defined on punch are schematically shown in Fig. 2.
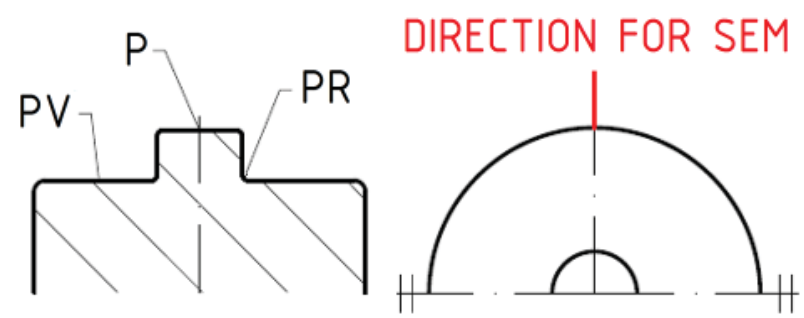

Fig. 2. Areas of interest for SEM and CM defined on punch; PV - Vicinity of punch protuberance, $\mathrm{P}$ - Protuberance of punch, PR - Radius around punch protuberance Obr. 2. Oblasti záujmu pre REM a KM definované na lisovníku
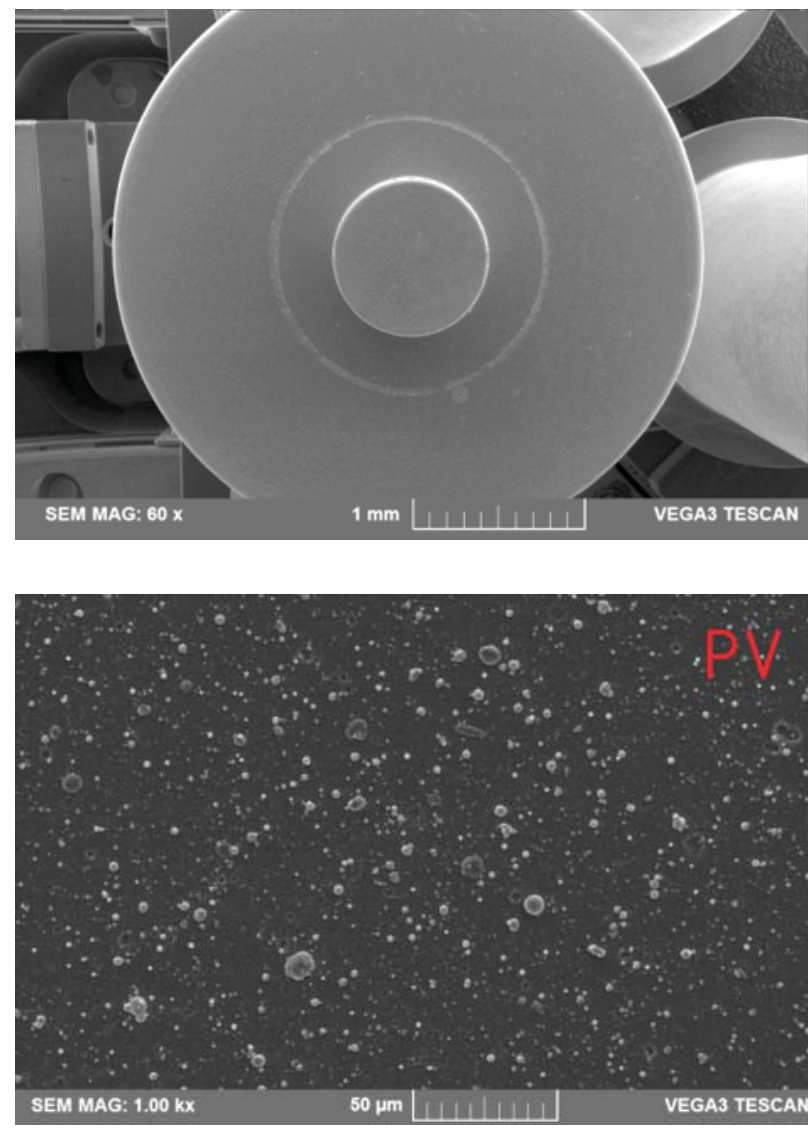

Fig. 3. Initial state of TiCN coating surface (SEM)

Obr. 3. Počiatočný stav povrchu povlaku TiCN (REM)
It was impossible to directly measure the surface of the clinching punch by confocal microscopy due to its dimensions. For this reason, the surface replication method was used to replicate the surface of punch and subsequently use replicas for contactless optical measurement by CM. The wear of coating was evaluated after each 50 manufactured joints starting with the initial state of tool (no manufactured joints).

\section{RESULTS}

\section{Initial state of coating}

Besides observation of SEM images, the following height parameters of surface texture were measured: Sqroot mean square height, Ssk - skewness, Sku - kurtosis, $\mathrm{Sp}$ - maximum peak height, $\mathrm{Sv}$ - maximum pit height, $\mathrm{Sz}$ - maximum height of the surface, $\mathrm{Sa}$ - arithmetic mean height, $\mathrm{Smr}$ - areal material ratio, Smc - inverse material ratio. Initial state of clinching punch with TiCN coating documented by SEM is shown in Fig. 3. Areas described in the previous chapter are marked red in top right corner of every image. Images show the areas of interest scanned with magnitude of $1000 \times$ except the top left image which was scanned with magnitude of
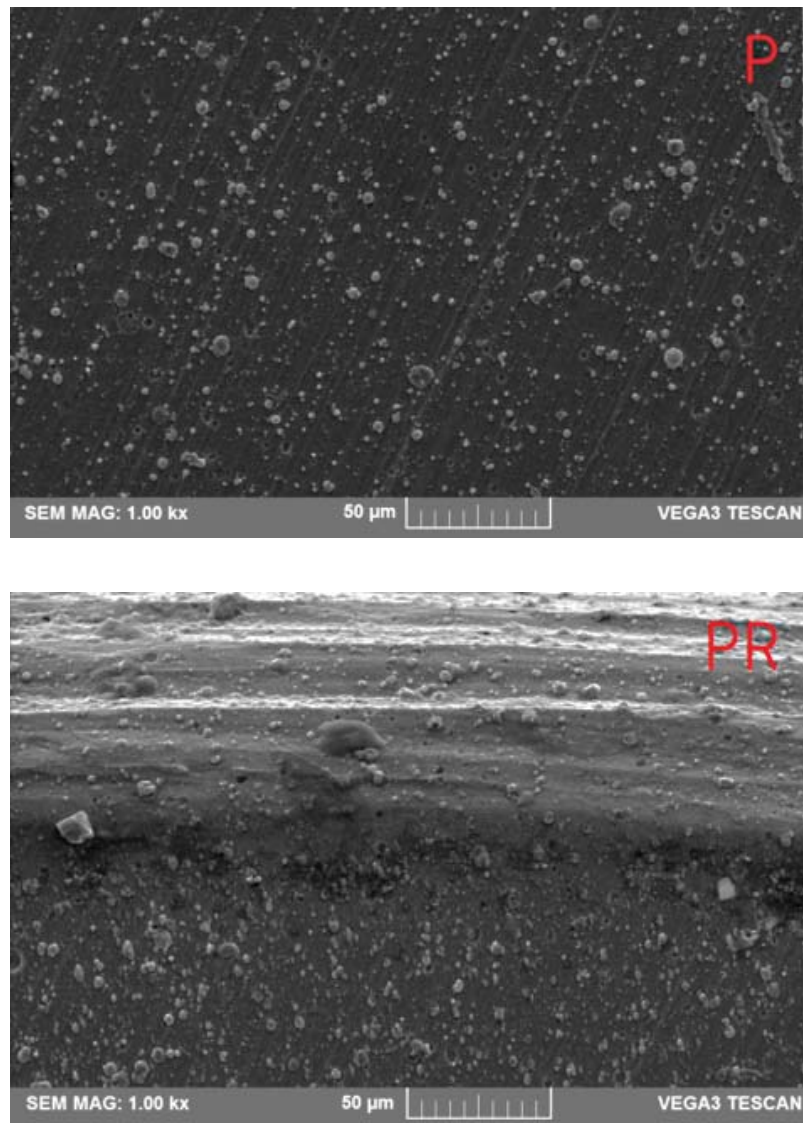
$60 \times$. Fig. 4 shows the punch with $\mathrm{CrN}$ coating scanned with the same conditions. The surface texture (height) parameters according to ISO 25178 are shown in Tab. 4. These parameters describe the state of the coating surface at the initial state for both clinching punches in area P.

Small droplets were clearly visible on surfaces of both punches ranging approximately from 1 to $5 \mu \mathrm{m}$. The density of these droplets was higher in the case of TiCN coating. Chrome and Titanium were detected in these droplets by energy dispersive X-ray analysis. The presence of these droplets is a result of LARC deposition technology. Grinding marks were observed in the areas $\mathrm{P}$ and PV on both surfaces of punches when 1000x and higher magnitudes were used. No visible discontinuities such as cracks were observed at the initial state of coating of both punches.
No significant difference between values of surface texture parameters can be seen, except for skewness parameter. Skewness values represent the degree of bias of the roughness shape of an asperity. The value of Ssk of TiCN coating is positive which refers to height distribution biased below the mean plane. Negative value of Ssk in the case of $\mathrm{CrN}$ coating refers to height distribution biased above the mean plane. Simply said, positive values of Ssk mean that peaks dominate over valleys and vice versa.

\section{Coating state after 100 manufactured joints}

State of TiCN coating surface after 100 manufactured joints documented by SEM is shown in Fig. 5. $\mathrm{CrN}$ coating deposited on punch after the same number

Tab. 4. Height and functional parameters in area P according to ISO 25178 / Výškové a funkčné parametre v oblasti „P“ $v$ zmysle ISO 25178

\begin{tabular}{|c|c|c|c|c|c|c|c|c|c|}
\hline & Sq $[\boldsymbol{\mu m}]$ & Ssk [-] & Sku $[-]$ & Sp $[\boldsymbol{\mu m}]$ & Sv $[\boldsymbol{\mu m}]$ & Sz $[\boldsymbol{\mu m}]$ & Sa $[\boldsymbol{\mu m}]$ & Smr $[\%]$ & Smc $[\boldsymbol{\mu m}]$ \\
\hline TiCN & 0.681 & 3.182 & 2059.21 & 53.350 & 55.543 & 108.893 & 0.351 & 0.00032 & 0.572 \\
\hline CrN & 0.865 & -5.423 & 1723.35 & 52.988 & 55.380 & 108.637 & 0.393 & 0.00129 & 0.641 \\
\hline
\end{tabular}
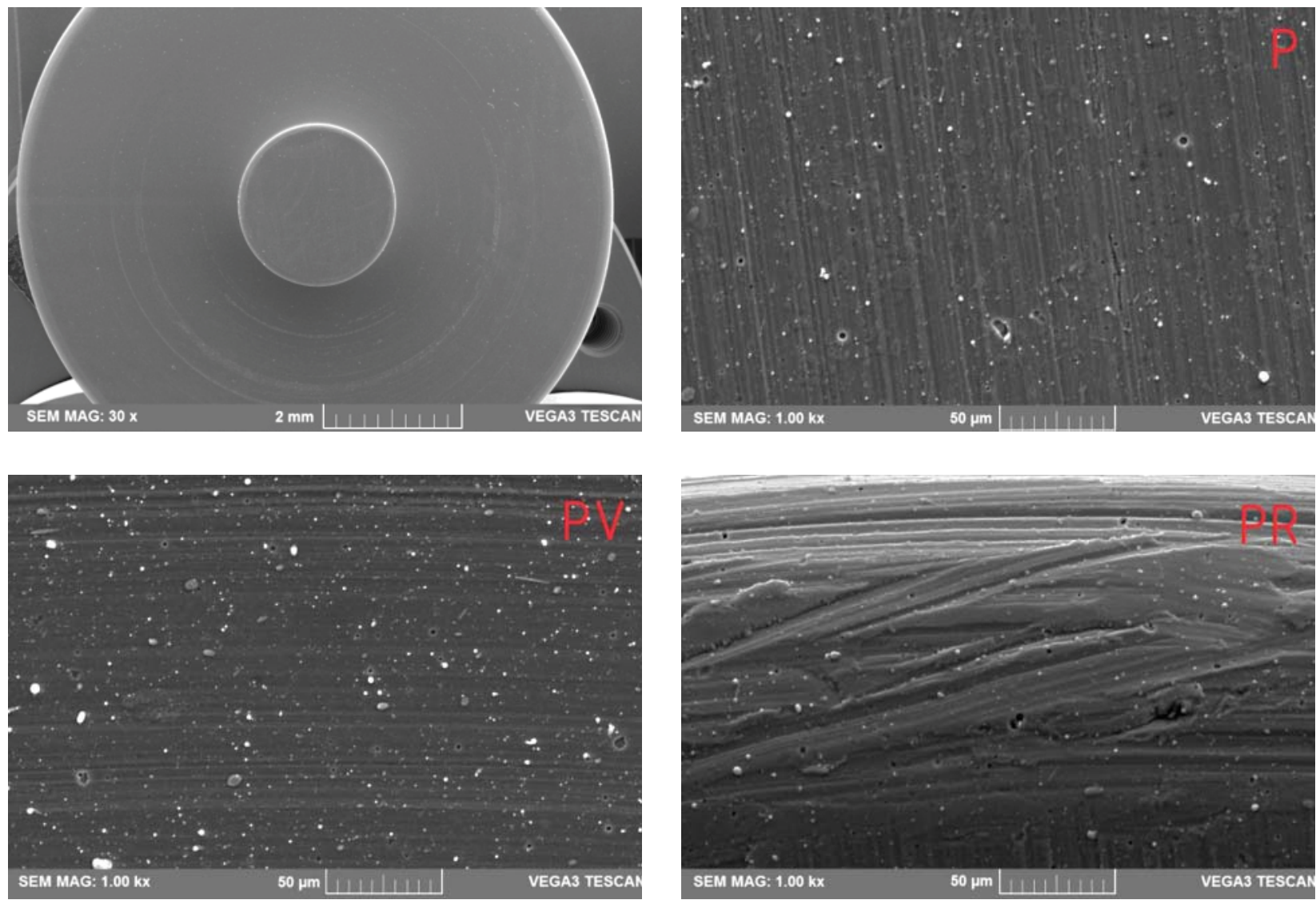

Fig. 4. Initial state of $\mathrm{CrN}$ coating surface (SEM)

Obr. 4. Počiatočný stav povrchu povlaku CrN (REM) 
of joints also documented by SEM is shown in Fig. 6 . Magnitude of $1000 \mathrm{x}$ was used in both cases. The same phenomenon can be observed in the case of both coatings when observing the PV area. This phenomenon is related to the density reduction of droplets located at the surface of coating because of running-in period of friction.

During this period, ploughing of the surface asperities takes place which leads to their deformation or detaching of droplets located at the surface of coating. This leads to density reduction of droplets of both coatings $\mathrm{CrN}$ and TiCN. Comparison of areas PV of both coatings (Fig. 3,4 versus Fig. 5,6 bottom left images) confirms this phenomenon. The surface texture (height) parameters according to ISO 25178 for both $\mathrm{CrN}$ and TiCN coatings are shown in Tab. 5. These values refer to changes in the $\mathrm{P}$ area after 100 manufactured joints by both clinching punches.
Values of Sq (root mean square height) increased in the case of $\mathrm{CrN}$ coating from $0.865 \mu \mathrm{m}$ up to $1.480 \mu \mathrm{m}$ and from $0.681 \mu \mathrm{m}$ up to $1.798 \mu \mathrm{m}$ in the case of $\mathrm{TiCN}$ coating. Similar increase was also observed for values of Sa (arithmetic mean height) parameter. This increase can be a sign of increased friction due to rapid increase of wear particles entrapped between sliding surfaces as a consequence of higher wear rate. Change of Ssk parameter (skewness) from positive to negative value can be observed for TiCN coating.

\section{Coating state after 200 manufactured joints}

SEM images of surface of TiCN coating are shown in Fig. 7. Areas of interest of $\mathrm{CrN}$ coating surface are shown in Fig. 8. Magnitude used in previous stages was not changed. In comparison with initial state, intensive

Tab. 5. Height and functional parameters in area P after 100 manufactured joints (ISO 25 178) / Výškové a funkčné parametre v oblasti „P“po 100 ks vyrobených spojoch (ISO 25 178)

\begin{tabular}{|c|c|c|c|c|c|c|c|c|c|}
\hline & Sq $[\boldsymbol{\mu m}]$ & Ssk [-] & Sku $[-]$ & Sp $[\boldsymbol{\mu m}]$ & Sv $[\boldsymbol{\mu m}]$ & Sz $[\boldsymbol{\mu m}]$ & Sa $[\boldsymbol{\mu m}]$ & Smr $[\%]$ & Smc $[\boldsymbol{\mu m}]$ \\
\hline TiCN & 1.798 & -2.000 & 91.348 & 70.630 & 34.269 & 104.899 & 1.095 & 2.184 & 1.609 \\
\hline CrN & 1.480 & -0.371 & 96.916 & 23.341 & 35.787 & 59.128 & 1.121 & 1.948 & 1.948 \\
\hline
\end{tabular}
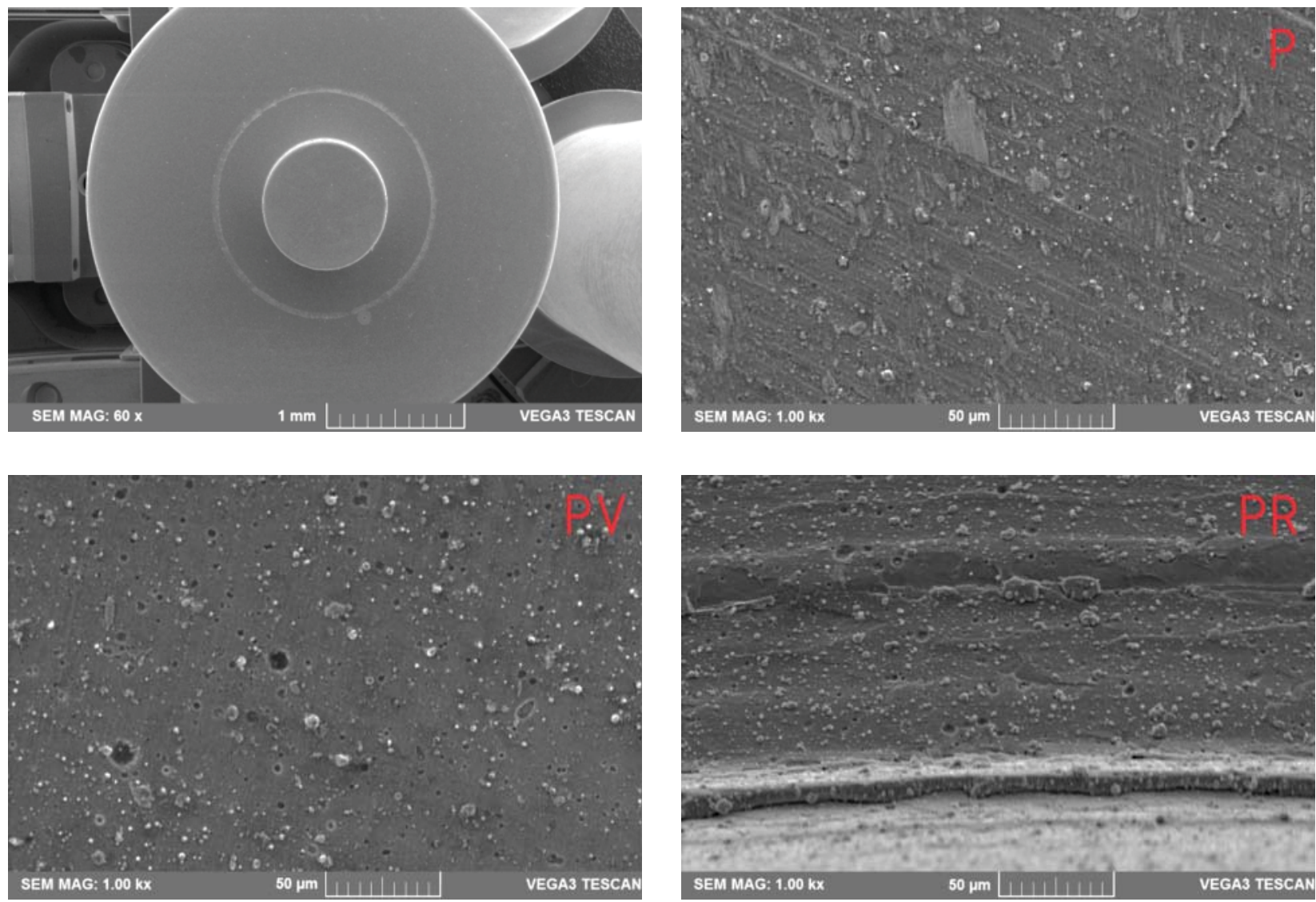

Fig. 5. TiCN coating surface after 100 joining cycles (SEM) Obr. 5. Povrch povlaku TiCN po 100 cykloch spájania (REM) 
removal of droplets can be seen in area PV of TiCN coating. Surface height and functional parameters according to ISO 25178 are shown in Tab. 6. Values of each parameter refer to the final state of the coating surface, i.e. after 200 joining cycles.

Some of the droplets were plastically deformed which is clearly visible in area $\mathrm{P}$ of TiCN coating (Fig. 7 top right). This is because of the direct contact of the punch protuberance with the joined material. Compressive loading of punch surface takes place, because of significant thickness reduction of the joined material. In this stage, surfaces of $\mathrm{TiCN}$ and $\mathrm{CrN}$ coating are polished, where large amount of surface asperities are removed. This could be confirmed by decrease of $\mathrm{Sa}$ and $\mathrm{Sq}$ parameter for both coatings. Moreover, this could be related to polishing of grinding marks when the surface of steel sheets moves perpendicular to their direction (see Fig. 8 top right). Decreasing tendency of values of Ssk (kurtosis) could refer to fact that sharpness of the roughness profile is decreasing. However, values of Ssk above 3 mean that height distribution is spiked.

The results of coating wear evaluation correspond with other scientific work published. Singer, Shimazaki and Bull observed the wear mechanisms of TiN coating when sliding to steel counter-surface. They made a conclusion that both surfaces become rougher and friction coefficient increases in the initial wear phase. Surface roughness has a distinctive influence on the coefficient of friction. An increase in surface roughness (parameter $\mathrm{Sa}$ ) was also observed in this research along with the coating wear in the initial phases of sliding against steel counter-surface. Bull and Rickerby concluded that $\mathrm{CrN}$ coating wear performance is approximately two orders of magnitude better than the TiN coating when the same loading conditions are applied. CrN coating wear performance was better compared to TiCN coating up to the last set of results [11].

Tab. 6. Height and functional parameters in area P after 200 manufactured joints (ISO 25 178) / Výškové a funkčné parametre voblasti „P“" po 200 ks vyrobených spojoch (ISO 25 178)

\begin{tabular}{|c|c|c|c|c|c|c|c|c|c|}
\hline & Sq $[\boldsymbol{\mu m}]$ & Ssk [-] & Sku [-] & Sp $[\boldsymbol{\mu m}]$ & $\mathbf{S v}[\boldsymbol{\mu m}]$ & Sz $[\boldsymbol{\mu m}]$ & Sa $[\boldsymbol{\mu m}]$ & Smr $[\%]$ & Smc $[\boldsymbol{\mu m}]$ \\
\hline TiCN & 1.471 & -0.950 & 76.695 & 60.464 & 40.344 & 100.808 & 1.022 & 2.184 & 1.864 \\
\hline CrN & 1.092 & 1.012 & 51.503 & 70.314 & 18.109 & 88.423 & 0.681 & 2.184 & 1.042 \\
\hline
\end{tabular}
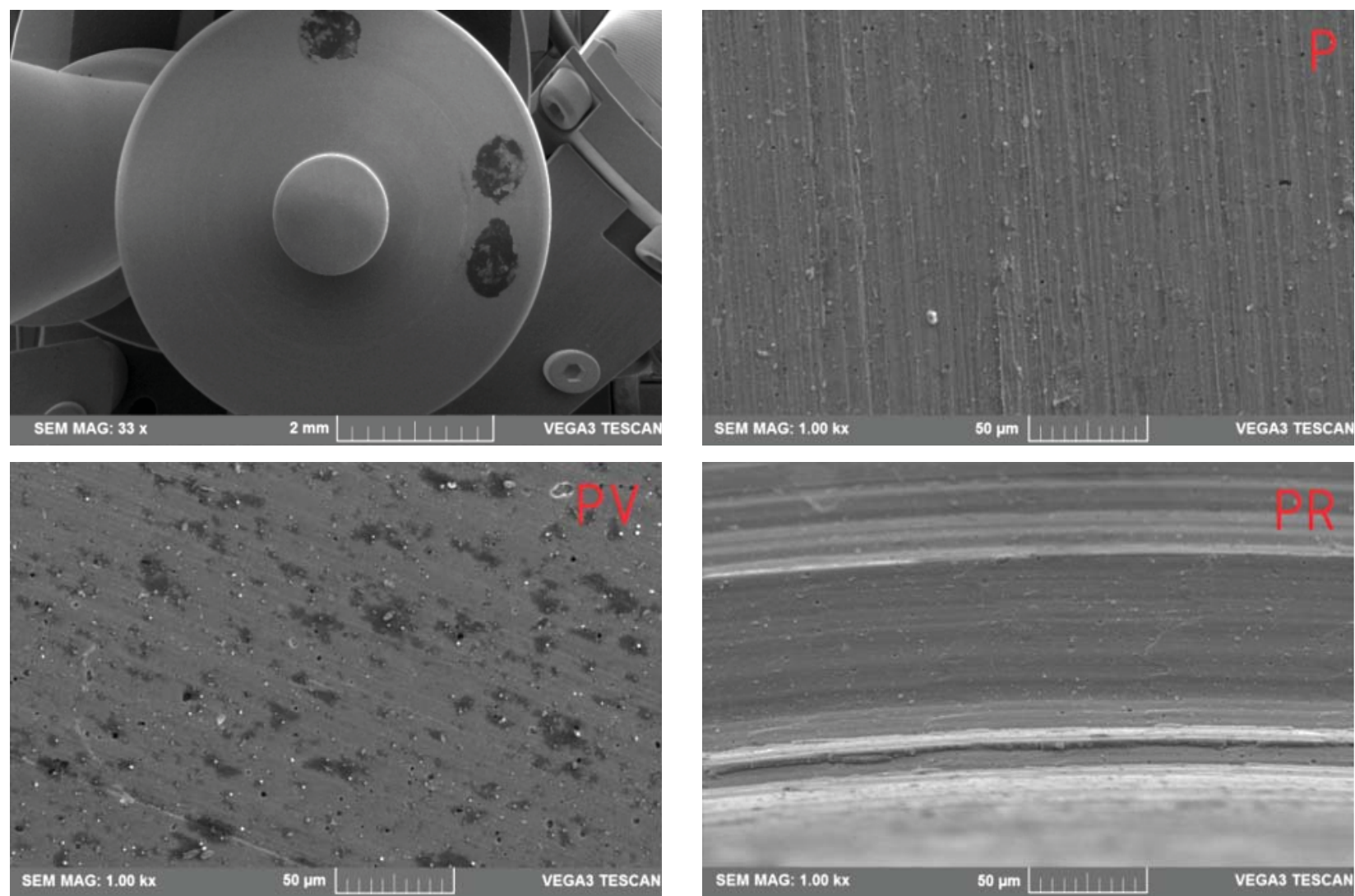

Fig. 6. CrN coating surface after 100 joining cycles (SEM) Obr. 6. Povrch povlaku CrN po 100 cykloch spájania (REM) 

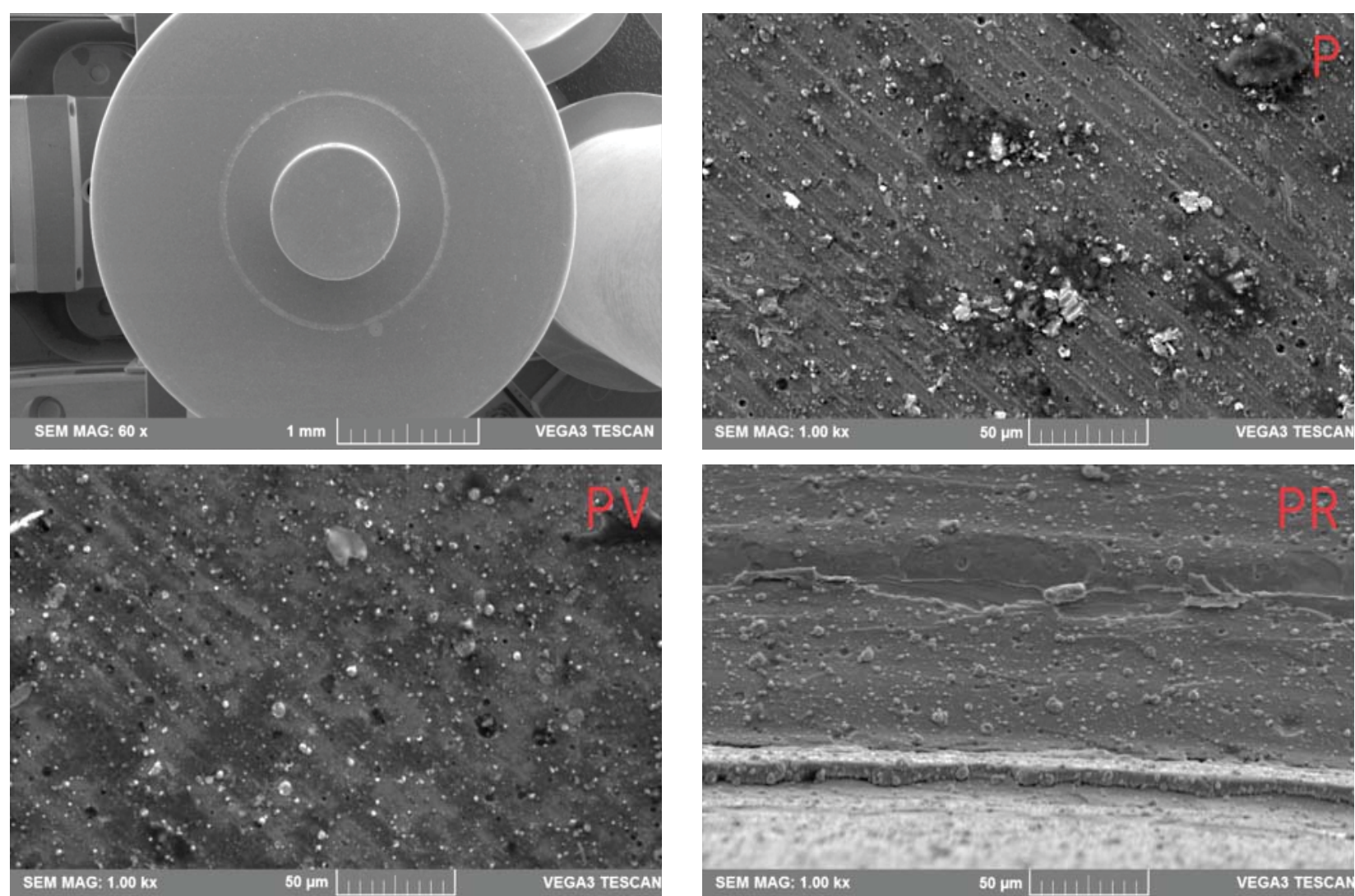

Fig. 7. TiCN coating surface after 200 joining cycles (SEM)

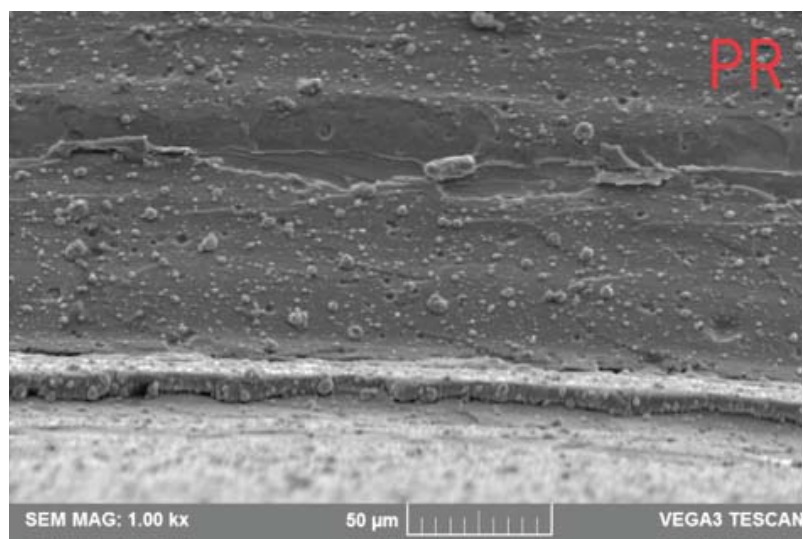

Obr. 7. Povrch povlaku TiCN po 200 cykloch spájania (REM)
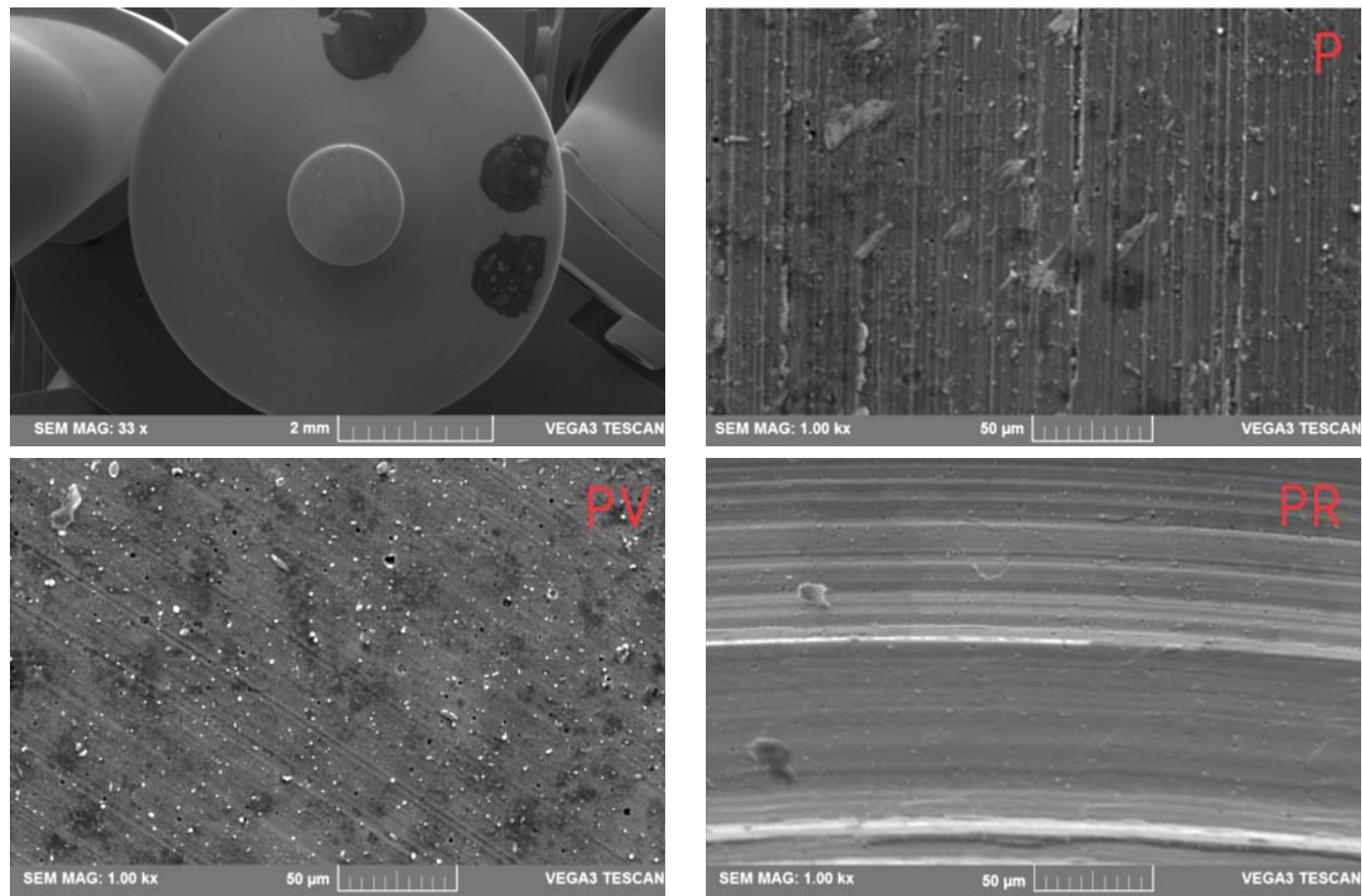

Fig. 8. CrN coating surface after 200 joining cycles (SEM)

Obr. 8. Povrch povlaku CrN po 200 cykloch spájania (REM) 


\section{CONCLUSIONS}

The wear of PVD coated tools for joining by clinching method was evaluated by scanning electron and confocal microscopy. Because of minor wear of the clinching die, only the surface of the punch was observed. Two coated punches (TiCN and CrN coatings) were used to join advanced high-strength dual-phase HCT600X steel sheets. Specifically chosen areas of tools were evaluated during early running-in period, starting with initial state of tools and ending with 200 manufactured joints. Following conclusions were stated:

- density reduction of droplets attached to coating surface during early running-in period takes place when steel slides across the surface of coating,

- height parameters Sq and Sa slowly decrease with progressing removal of droplets,

- height parameter Sku tends to decrease, i.e. sharpness of roughness profile is reduced when joined material slides perpendicularly to grinding marks,

- in spite of the high strength of the joined material and resulting high compressive load of the punch, no cracks or coating detachments were observed during experiment,

- the surface of the punch protuberance was less damaged in the case of TiCN coating when compared to $\mathrm{CrN}$ coating; this could be related to its higher indentation hardness.

\section{Acknowledgements}

This work was supported by the project VEGA No. 1/0872/14.

\section{REFERENCES}

1. Sprute T. et al. Influence of substrate pre-treatments on residual stresses and tribo-mechanical properties of TiAlNbased PVD coatings, Surface \& Coatings Technology 2014, 260, 369-379.

2. Ibrahim R.N. et al. Monolayer TiAlN and multilayer TiAlN/ CrN PVD coatings as surface modifiers to mitigate fretting fatigue of AISI P20 steel, Engineering Fracture Mechanics 2015, 137, 64-78.

3. Skordaris G., Bouzakis K.-D., Charalampous P. A dynamic FEM simulation of the nano-impact test on mono- or multilayered PVD coatings considering their graded strength properties determined by experimental-analytical procedures, Surface \& Coatings Technology 2015, 265, 53-61.

4. Rizzo A. Improved properties of TiAlN coatings through the multilayer structure, Surface \& Coatings Technology 2013, 235, 475-483.

5. Calabrese L. et al. Effects of ageing on mechanical durability of round clinched steel/aluminium joints, International Journal of Mechanical and Materials Engineering 2014, 9, 1-10.

6. Mucha J., Kaščák L'., Spišák E. The experimental analysis of Cold Pressed Joint Technology for Selected Sheet Metals used in an Automotive Industry, Advanced Materials Research 2014, 1077, 33-38.

7. Jiang T., Liu Z.X., Wang P.C. Effect of aluminum prestraining on strength of clinched galvanized SAE1004 steelto-AA6111-T4 aluminum, Journal of Materials Processing Technology 2015, 215, 193-204

8. Mucha J., Witkowski W. The clinching joints strength analysis in the aspects of changes in the forming technology and load conditions, Thin-Walled Structures 2014, 82, 55-66.

9. Kaščák L. et al. Clinching - an Innovative Trend in Joining of Combined Materials in Car Body Production, Materials Science Forum 2015, 818, 217-220.

10. Groche P. et al. Joining by forming - A review on joint mechanisms, applications and future trends, Journal of Materials Processing Technology 2014, 214, 1972-1994.

11. Holmberg K., Matthews A. Coatings Tribology: Properties, Mechanisms, Techniques and Applications in Surface engineering, 560 p., 2009. ISBN 978-0-4445-2750-9 